Gomółka K., Polish-Russian cooperation of Pomorskie Province, „Economics and Law”, Polszakiewicz B., Boehlke J. (ed.), Vol. 13, No. 1/2014, pp. 95-108. DOI: http://dx.doi.org/10.12775/ EiP.2014.008

\title{
POLISH-RUSSIAN COOPERATION OF POMORSKIE PROVINCE
}

\author{
SUMMARY
}

Polish-Russian Cooperation of Pomorskie Province commenced in 1999 and was based on the intergovernmental agreements. The new agreement, executed between the authorities of the Pomeranian Province and Kaliningrad Oblast in 2002, provided for cooperation in many areas. The contacts between the partners were dominated by economic cooperation. The Polish-Russian cooperation stopped with Polish accession to the Schengen zone. Cooperation resumed when in 2011 and agreement on small cross-border traffic was signed and then ratified in 2012.

Keywords: agreements, small cross-border traffic, administrative reform JEL Classification: Z18, F55

\section{INTRODUCTION}

The cooperation between Pomorskie province and its Russian partner was preceded by the contacts established in the early 1990s by Gdańsk voivodeship and later on by Elbląg voivodeship and Olsztyn voivodeship. Shortly after the Treaty of Good Neighbourship and Friendly Cooperation was signed

"Krystyna Gomółka, Gdańsk University of Technology, Faculty of Management and Economics, Department of social sciences and philosophy, ul Traugutta 79, 80-233 Gdańsk, phone: +48 5834722 42, e-mail: Krystyna.Gomolka@zie.pg.gda.pl. 
on 22 May 1992 between Russia and the Republic of Poland, in June 1992 an agreement was executed between Gdańsk voivodeship and Kaliningrad Oblast. The agreement provided for bilateral cooperation in the domains of: trade, sea transport, agriculture, tourism, communication, culture and science ${ }^{1}$. Since 1992, based on the agreement done between the Government of the Republic of Poland and the Government of the Russian Federation on 2 October 1992, Gdańsk voivodeship participated in the works of the Polish-Russian Council for Cooperation between Kaliningrad Oblast and the Northern Regions of the Republic of Poland, the aim of which was to set the direction and coordinate the development of the Polish-Russian cooperation. In 1993, the Labour Office in Gdańsk established contacts with the Kaliningrad Regional Labour Centre. The agreement concluded between the Duma in Kaliningrad and the Sejmik of Gdańsk Voivodeship in 1997 was the last document signed before the administrative reform in Poland, as a result of which Pomorskie province was formed. The objective of this paper is to present and analyse the direct forms of Polish-Russian cooperation between Pomorskie province and Kaliningrad Oblast in its legal and practical dimensions. The paper covers the period between 1998 and mid-2013.

\section{COOPERATION REFLECTED IN LEGAL DOCUMENTS AND STRATEGIES}

Pomorskie province was created as a result the 1998 administrative reform and encompassed the geographical area of the whole Gdańsk voivodeship, Słupsk voivodeship less Sławieński poviat, some of the communes (gminas) of Nowodworski, Malborski, Sztumski and Kwidzyński poviats (which

1 The agreements were executed on the basis of agreements done at intergovernmental level: The Treaty of Good Neighbourship and Friendly Cooperation between the Republic of Poland and the Russian Federation, signed on 22 May 1992 in Moscow, Journal of Laws of 1993, No. 61, it. 291; The Agreement between the Government of the Republic of Poland and the Government of the Russian Federation on cooperation of the north-eastern voivodeships in Poland and Kaliningrad Oblast; The Agreement between the Government of the Republic of Poland and the Government of the Russian Federation on cooperation of Polish voivodeships with the region of Saint Petersburg of 22 May 1992 - the text of the agreement in: T. Baryła, W. Hojszyk (ed.), Regiony i Pogranicza. Kaliningrad. Fakty $i$ wydarzenia, opinie, TN, OBN Olsztyn, Olsztyn 2007, No 2; The Agreement between the Government of the Republic of Poland and the Government of the Russian Federation on cross-border cooperation of 2 October 1992 [in:] A. PrzyborowskaKlimczak, W. Staszewski, S. Wrzosek (ed.), Prawnomiędzynarodowe źódta wspótpracy regionalnej wspótpracy regionalnej Polski. Wybór dokumentów. Wydawnictwo Ekonomia i Środowisko, Fundacja Ekonomistów Środowiska i Zasobów Naturalnych, Białystok 2000, p. 46. 
were formerly part of Elbląg voivodeship) and communes of Chojnicki poviat (formerly part of Bydgoszcz voivodeship). Pomorskie encompassed four cities with the rights of poviats: Stupsk, Gdynia, Sopot, Gdańsk, as well as 16 poviats, 25 municipalities, 17 urban-rural communes and 81 rural communes ${ }^{2}$. The border between Pomorskie and Kaliningrad Oblasts runs across the Vistula Spit. The legal grounds for the development of the cooperation in the researched period are provided, beside the previously concluded agreements between Poland and the Russian Federation, by the agreements regarding Poland's accession to Schengen area and introduction of visa requirements, the agreement on the sailing on the Vistula Lagoon, and the agreement on small cross-border traffic ${ }^{3}$. The foreign cooperation of Pomorskie is also based on the documents adopted by sejmiks: 'The Priorities of the Foreign Cooperation of Pomorskie Province' and 'The Strategy for the Development of Pomorskie Province,' which set up the objectives, the directions and the types of foreign cooperation of the province. The document entitled 'The Priorities of the Foreign Cooperation of Pomorskie Province' provides that the international cooperation of the province should be consistent with the principles of foreign policy of Poland and should result from the geographical location of the region, the transit functions of sea ports, the economic and intellectual potential of the area, its cultural heritage and ethnic diversity. The main geographical direction of cooperation was assumed to be the Baltic Sea Area, encompassing: in Germany - the State of Schleswig-Holstein and the State of Mecklenburg-Vorpommern, in Denmark - the Storstrøm County and Bornholm, in Sweden - Kalmar, Blekinge, Kronoberg and Skania, certain regions in Norway and Finland, in Russia - Kalinigrad Oblast and Saint Petersburg, and some regions in Estonia, Latvia and Lithuania. The document indicated also that the representatives of the local government participated in the works of the institutions and international organisations operating in the Baltic Sea region, the Baltic Euroregion, the Conference on the Baltic Sea States Subregional Cooperation, and in the following Baltic programmes: VASAB 2010,

${ }^{2}$ Pomorskie.eu, The administrative division of Pomorskie province, http://www.pomorskie.eu/ pl (01.07.2013).

3 The Agreement between the Government of the Republic of Poland and the Government of the Russian Federation on the travelling conditions of citizens of both states of 18 September 2003, Law Gazette, No. 51/2003, it. 800; The Agreement between the Government of the Republic of Poland and the Government of the Russian Federation on the sailing on the Vistula Lagoon of 1 September 2009, Law Gazette, No. 78/2009, it. 975; Act of 16 March 2012 on the ratification of the Agreement between the Government of the Republic of Poland and the Government of the Russian Federation executed in Moscow on 14 December 2011, Journal of Laws of 2012, No. 16 it. 498. 
Baltic Marine Environment Protection Commission HELCOM, Agenda 21 for the Baltic Sea Region, Union of the Baltic Cities ${ }^{4}$.

The other document that specifies the objectives and the tasks of the foreign cooperation encompasses the so-called strategies. 'The Strategy for the Development of Pomorskie Province' has been changed three times in the period between 1998 and 2013. The first strategy, of 2000, expressed support for the contacts between Pomorskie in Poland and Kaliningrad Oblast in Russia and cross-border cooperation, and pointed out the need for a new agreement to be signed in view of the administrative reform ${ }^{5}$. The updated strategy for the development of Pomorskie province, of 2005, emphasised the fact that Pomorskie was playing an active role in the cooperation with the Russian Federation, for example participating in the works of the Baltic Euroregion part of Interreg IIIA EU Initiative, which made it possible to establish bonds between all the members of the so-called South Baltic Development Zone. The strategy considered the following issues to be of vital significance for the future of the area: establishing the development areas along transport corridors, taking care of marine environment, protecting the cultural and natural heritage, creating conditions for investments as well as innovative and competitive development ${ }^{6}$. The strategy of 2011 drew special attention to the areas of trans- and international cooperation within the South Baltic region. The cooperation was to cover: development of sea and air traffic, cluster collaboration, creation of the accelerated development zones along transport corridors of European significance, construction of international power grids, activities that aim at improving the quality of the Baltic Sea waters and the integrity of the natural environment, international scientific cooperation between the South Baltic States, creation of the image and tourist brand of the Baltic Sea region, support for cultural exchange, and creation of international educational programmes that aim at raising the ecological awareness of the local citizens ${ }^{7}$.

${ }^{4}$ Pomorskie.eu, The Priorities of the Foreign Cooperation of Pomorskie Province, http://www.pomorskie.eu/res/BIP/UMWP/wojewodztwo/wspolpraca_zag.pdf (05.07.2013).

${ }_{5}$ Pomorskie Province Office in Gdańsk, Strategy for the development of Pomorskie province, Gdańsk 2000, pp. 3, 10.

${ }^{6}$ Pomorskie Province Office in Gdańsk, Strategy for the development of Pomorskie province, http://strategia2020.pomorskie.eu/res/strategia2020/strategia2005/asrwp_tekst_jednolity_ostateczny_180705.pdf (02.07.2013).

7 Pomorskie Province Office in Gdańsk, Strategy for the development of Pomorskie province until 2010, http://urzad.pomorskie.eu/res/umwp/dokumenty/pomorskie_srwp2020.pdf (03.07.2013). 


\section{PRACTICAL IMPLEMENTATION OF THE POLISH-RUSSIAN CO-OPERATION}

The practical implementation of the Polish-Russian cooperation commenced in 1999 with the participation of the Marshal of Pomorskie (Marszałek województwa pomorskiego) in the conference on cross-border cooperation, organised in March that year in Kaliningrad. The talks focused on the shape and the principles of collaboration between the two regions. A joint document was presented in Kaliningrad in February 2000 during the meeting between the delegation from Pomorskie and the representatives of Kaliningrad Duma ${ }^{8}$. The first agreement that was finalized as part of the activities of Pomorskie was the agreement on mutual cooperation between the town of Starogard Gdański and the Central Administrative Region of Kaliningrad, executed in May 2000 during the Economic Forum Starogard Gdański - Kaliningrad 9 . In 2001, the parties conducted talks on concluding agreements at the regional authorities level. In April 2001, the Gdańsk Institute for Market Economics organised a debate on the barriers in cooperation with the Russians, while in November that year a forum was held on the future of Kaliningrad Oblast in the expanding Europe ${ }^{10}$. Following the Polish-Russian seminar in January 2002, on 27 February that year, an agreement on the cooperation between Kaliningrad Oblast and Pomorskie Province as well as an agreement on the cooperation between Sejmik of Pomorskie and Duma of Kaliningrad Oblast were executed ${ }^{11}$. They envisaged cooperation between the partners in the fields of economy, politics and culture. Up until the end of 2002, a few training sessions and seminars on how to create a model of collaboration between non-governmental organisations and local governments were organised. In 2003, the contacts between the regions were dominated by economic

${ }^{8}$ Pomorskie Province Office in Gdańsk, Meeting between the delegation from Pomorskie province and the representatives of Kaliningrad Duma in February 2000, Gdańsk 2000.

9 Pomorskie Province Office in Gdańsk, Economic Forum, Starogard Gdański 2000.

${ }_{10}$ Pomorskie Province Office in Gdańsk, Polish-Russian Debate: The future of Kalinin-grad Oblast in the expanding Europe, Gdańsk.

${ }_{11}$ Pomorskie.eu, The Agreement on cooperation between Pomorskie Province (Republic of Poland) and the Administration of Kaliningrad Oblast (Russian Federation) of 27 February 2002, http://www.pomorskie.eu/pl/bip/umwp/urzad/sprawy/sprawy_do_zalatwienia/dwz_porozumienia (07.07.2013); Pomorskie.eu, The agreement on the cooperation between Sejmik of Pomorskie and Duma of Kaliningrad Oblast of 27 February 2002, http://www.pomorskie.eu/pl/bip/umwp/urzad/ sprawy/sprawy_do_zalatwienia/dwz_porozumienia (07.07.2013). 
issues. Friedrich Ebert Foundation hosted a conference entitled 'Kaliningrad - investment opportunities.' The same year, 'POLEXPORT KALINIGRAD 2003' Polish National Exhibition took place and Polish and Russian entrepreneurs attended a meeting on the quality of products ${ }^{12}$. The year 2004 allowed cooperation in numerous fields to advance. In February that year, Consulate of the Republic of Poland in Kaliningrad hosted the workshop on 'The perspectives of cultural cooperation between Pomorskie and Kaliningrad Oblast in view of EU extension,' which focused on the possibilities of joint application for EU grants. The participants of the meeting between the authorities of the University of Gdańsk, Faculty of Philology and History and the authorities of Kaliningrad State University, Faculty of Slavic Philology and Journalism discussed the possibilities of conducting joint scientific research and implementing joint projects within Euroregion Baltic ${ }^{13}$. In June, University of Gdańsk, the Department of Regional Development organised a conference entitled 'Regional development in the borderlands of north-eastern Poland and Kaliningrad Oblast.' Two months later, in Tczew, two Russian theatres from Kaliningrad showed their performances ${ }^{14}$.

As far as educational contacts are concerned, the issues that need to be mentioned comprise the attendance of the representatives of Pomorskie local government in the celebrations of the 10th anniversary of Kaliningrad Oblast Duma and the preparation to the implementation of the project under which the Polish local authorities would share with Russian partners their experience regarding the local governments reform of $1998^{15}$. In 2005, The Marshal's Office in Gdańsk in cooperation with Kaliningrad University and the administrative authorities of Baltiysk commenced implementation of the 'Project of Economic Revitalisation of the Vistula River Delta and the Vistula Lagoon.' The aim of the project was to work out a program of complementary socioeconomic, ecological and spatial development in which two Polish provinces, Pomorskie and Warmińsko-Mazurskie, would cooperate. Involved in the project were 36 gminas located in the Vistula river delta and its immediate vicinity comprising the internal water basins and the Vistula Lagoon ${ }^{16}$.

12 Pomorskie Province Office in Gdańsk, 2003 Activity Report. Polish-Russian co-operation, Gdańsk 2004.

${ }_{13}$ Pomorskie Province Office in Gdańsk, Memo. Cooperation with Euroregion Baltic, Gdańsk.

${ }^{14}$ Rzeki.art.pl, Tczew bulwar, aktywna przestrzen, http://www.rzeki.art.pl/filemanager/file/prezentacje/Tczew_bulwar.pdf (07.07.2013).

15 Pomorskie Province Office in Gdańsk, Wizyty studyjne, Gdańsk 2005.

16 Pomorskie Province Office in Gdańsk, Project of Economic Revitalisation of the Vistula River Delta and the Vistula Lagoon, Agreement no. FW-SPF-97/2003/710/II of 6 July 2005 financed by the European Union funds under PHARE 2003 as part of Polish Eastern Border imple- 
In the years 2006-2007 Pomorskie Province and Kaliningrad Oblast took part in the project entitled 'Culture and Art,' whose direct implementers were the Association of Polish Communes Euroregion Baltic and the Education Centre for Lawyers in Kaliningrad. The aim of the project was to create an international network of permanent cooperation that would serve educational advancement of those employed in the sector of culture, to organise joint enterprises and to distribute information on cultural events. Further stages of the project envisaged formation of the Polish-Russian Council on Culture as well as organisation of international training on Polish-Russian projects ${ }^{17}$. Further practical cooperation in the field of culture manifested itself in the organisation, in May 2006, of the 19th National Festival of Sea Songs, accompanied by the International Seminar for Conductors. The organisation of the two events was possible thanks to the funds from the Good Neighbourship Programme - Poland-Lithuania-Russian Federation (Kaliningrad Oblast) Interreg IIIA. The festival was attended by choirs from all around Poland as well as three foreign ones, including 'The Songs of Ukraine' choir from Kaliningrad ${ }^{18}$. Another event in the Polish-Russian relations were the $2^{\text {nd }} \mathrm{Eu}-$ roregion Baltic Youth Games, which were part of the project whose aim was to enhance the social activity in the Euroregion Baltic by continuing the tradition of youth sports games held in the spirit of integration, European solidarity and tolerance. The Games were attended by competitors from 9 countries, including Russian Federation - the cities of Kaliningrad and Baltiysk ${ }^{19}$.

As part of their political cooperation, in the year 2006 the authorities of Pomorskie and the authorities of Kaliningrad Oblast organised a conference under the title 'The Schengen accession of Poland and Lithuania: consequences and perspectives of the border cooperation between Kaliningrad Oblast and its neighbours.' The conference was devoted to the problems of sealing the eastern EU border and its impact on the cross-border traffic ${ }^{20}$. The discussion on the subject was continued during the meeting in October 2007 with the representatives of Russian administration, which focused on the cooperation between Pomorskie and Kaliningrad Oblast, and the Forum of Partner Re-

mented by the Association of Polish Communes Euroregion Baltic, http://www.pomorskie.eu/ res/wizytowka/rolnictwo/program_rewitalizacji.pdf (07.07.2013).

17 Report on the implementation of 'Culture and Art' Project (electronic document) www. eurobalt.org.pl as of 10 March 2008 cited in: K. Gomółka, Wspótpraca transgraniczna Polski z Republikq Ukrainy, Republikq Biatorusi i Obwodem Kaliningradzkim Federacji Rosyjskiej, Wyd. Semper, Warszawa 2011, p. 145.

18 Pomorskie Province Office in Gdańsk, Memo. Festival of Sea Songs, Gdańsk 2006.

$192^{\text {nd }}$ Euroregion Baltic Youth Games, „Euroregion Baltic Bulletin”, No. 1/2007.

${ }^{20}$ Seagull in a nutshell, „Euroregion Baltic Bulletin”, No. 3/2007. 
gions of Kaliningrad Oblast in September $2008^{21}$. During the following meeting of the regions, held in October 2009, the partners discussed the tourist potential of the Baltic Sea states, the possibilities of cooperation between the regions, and the possibility of obtaining funds from EU programmes. Another conference that coincided in time with the one mentioned above was a conference on 'The Perspectives of Youth Entrepreneurship and the Development of Tourism in the Baltic Sea States,' which was attended by three representatives of Pomorskie local governments ${ }^{22}$.

In the years to follow, Polish-Russian relationships concentrated on the cooperation in the fields of tourism and culture. In April 2010, Polish delegation participated in the Herring Day ceremonies, a yearly event held in $\mathrm{Ka}^{-}$ liningrad by the Museum of World Ocean. The Polish participants prepared the promotional stand with regional dishes, for which they received an honorary diploma 'The herring outside the city walls.' As for tourist events, the cruises between Baltiysk and Gdynia were resumed. It was possible owing to 2009 agreement on the traffic on the Vistula Lagoon ${ }^{23}$. In November 2010, the representatives of Pomorskie participated in the $3^{\text {rd }}$ Tourism Forum of the Baltic Sea Region, which was held in Kaliningrad and focused on: sea tourism, health tourism and historical tourism ${ }^{24}$. Tourism blazed the trail for the development of economic relations between Pomorskie and the authorities of Kaliningrad Oblast. As a result of common arrangements, in February 2012 the Baltic Philharmonic Hall held the Baltic Business Forum - Gdańsk 2012. The Forum comprised two modules. During the first one, Pomorskie and Kaliningrad Oblast presented their economic potential as well as tools that could support Polish and Russian entrepreneurs who are entering the neighbour's market - mainly banking and insurance products. The second module comprised five trade sessions, which focused on: $1 /$ construction industry and infrastructure, 2/ marine industry and economy; 3/ agricultural industrial sector and processing industry; 4/ tourism; 5/ cooperation and partnership of local governments. During the session concerned with cooperation of local governments, the communes of Sztutowo and Pioniersk executed a letter of in-

${ }^{21}$ Pomorskie Province Office in Gdańsk, Report on the meeting in October 2007, Gdańsk 2008; Pomorskie Province Office in Gdańsk, Report on the participation in the Forum of Partner Regions of Kaliningrad Oblast, Gdańsk 2008.

${ }^{22}$ Pomorskie Province Office in Gdańsk, $2^{\text {nd }}$ Forum of Partner Regions of Kaliningrad Oblast, Gdańsk.

${ }_{23}$ Trojmiasto.pl, Do Battyjska poptyniemy juz w sobote, http://www.trojmiasto.pl/wiadomosci/Do -Baltijska-poplyniemy-juz-w-sobote-n41837.html (08.07.2013).

${ }^{24}$ Pomorskie Province Office in Gdańsk, $3^{\text {rd }}$ Tourism Forum of the Baltic Sea Region, Gdańsk 2010. 
tent. Moreover, the representatives of the communes of Kaliningrad Oblast conducted a study visit to Pruszcz Gdański, where they met with local authorities, visited Faktoria, Sports and Recreation Centre and Care Centre for the Disabled in Starogard Gdański, participated in a meeting with the mayor of the town, and paid a visit to the communal waste recycling plant in Stary $\mathrm{Las}^{25}$. The fact that the forum was attended by 330 participants proves that the interest in mutual contacts is high.

In March 2012, Polish-Russian cooperation moved to the field of science. The contacts between Gdańsk Science and Technology Park and its partner in Kaliningrad Oblast became tighter. During the meeting, attended by the representatives of IT and ICT sectors the participants tried to establish common areas of interest. The Polish attendants became aware of the investment possibilities in Kaliningrad Obalsts, the conditions for the operation of the special economic zone in Kaliningrad and the plans for economic development of that region. Further meetings of the representatives of Polish and Russian local governments concerned economic aspects of their cooperation. In September 2012, Gdańsk Science and Technology Park concluded an agreement with the Kaliningrad Region Development Corporation, while in November that year the representatives of Pomorskie took part in the talks of the Polish-Russian Intergovernmental Commission on Economic Cooperation, the Working Group on Trade and Investment ${ }^{26}$.

Since 27 July 2012, that is the date when the so-called small cross-border traffic was initiated, Polish-Russian cooperation has gained a new dimension. The citizens of Kaliningrad Oblast and some of the citizens of Pomorskie province have been equipped with special permits and can travel across the border under visa free regime ${ }^{27}$. The agreement on small cross-border traffic has significantly intensified contacts between Pomorskie and Kaliningrad Oblast. The events that were organised until the end of June 2013 were mainly of economic character. The first of them was the conference 'The Vistula Lagoon - prospects of development and the use of its socio-economic potential in the course of Polish-Russian cooperation,' which was held in January. Also in January 2013 a seminar for companies from Pomorskie province was

25 Pracodawcypomorza.pl, Battyckie Forum Biznesu 2012 r., http://pracodawcypomorza. $\mathrm{pl} / 2012 / 01 / 27 /$ baltyckie-forum-biznesu-gdansk-2012-9-02-2012/ (08.07.2013).

${ }^{26}$ Pomorskie Province Office in Gdańsk, Information on the talks of the Polish-Russian Intergovernmental Commission on Economic Cooperation, The Working Group on Trade and Investment, Gdańsk.

27 Act of 16 March 2012 on the ratification of the Agreement between the Government of the Republic of Poland and the Government of the Russian Federation executed in Moscow on 14 December 2011, Journal of Laws of 2012, No. 16 it. 498 
organised by two organisations: Gdańsk Employers Association and Centre for Business Cooperation 'Poland-Russia.' Another impulse for the development of the economic relations was provided by Tourism Fair in April 2013, in which the Russian Federation was the main partner. In June, the representatives of Pomorskie province took part in the conference in Kaliningrad on how Kaliningrad can use Polish experience to prepare for the organisation of World Football Championships 2018. The Russians presented cooperation opportunities for Polish entrepreneurs who would like to use the coming years to invest intensively in Kaliningrad Oblast.

\section{CONCLUSIONS}

It was only in 2002 that Pomorskie province, which was created in the effect of the administrative reform, executed a cooperation agreement with Kaliningrad, even though practical contacts between the partners had already been taking place under the bilateral agreements between the relevant states - Poland and the Russian Federation. Cooperation with Russian partner was reflected in the subsequent strategies of Pomeranian province, taking into account the priorities of Polish foreign policy. The cooperation with Kaliningrad Oblast was conducted in various fields: politics, economy, tourism and culture. Since 1999 the economic domain of cooperation has generally prevailed, especially in the tourism sector, it would sometimes give place to cooperation in the fields of science or culture what especially was observed after 2004. Much less meetings were recorded on the political area, the vast majority of them concerned the transfer of good practices with the Pomeranian local government to Kaliningrad. It was noted the lack of joint ventures in the field of environmental protection. The most commonly implemented forms of cooperation include: seminars, training, conferences, workshops and trade fairs. Many Polish and Russian institutions collaborated on projects with programs: Phare CBC, Interreg IIIA, the Norwegian Financial Mechanism. The both partners exhibited the capacity to initiate collaboration, but more often it did the Polish side. Polish accession to the Schengen zone resulted in a reduction in the number of Polish-Russian contacts. However, they were revived following the execution of the Polish-Russian Agreement on Small Cross-Border Traffic. It has meant more dynamic development of relations mainly of an economic nature. 


\section{BIBLIOGRAPHY}

$2^{\text {nd }}$ Euroregion Baltic Youth Games, „Euroregion Baltic Bulletin”, No. 1/2007.

Act of 16 March 2012 on the ratification of the Agreement between the Government of the Republic of Poland and the Government of the Russian Federation executed in Moscow on 14 December 2011, Journal of Laws of 2012, No. 16 it. 498.

Act of 16 March 2012 on the ratification of the Agreement between the Government of the Republic of Poland and the Government of the Russian Federation executed in Moscow on 14 December 2011, Journal of Laws of 2012, No. 16 it. 498

Eurobalt.org.pl, Report on the implementation of 'Culture and Art' Project, www.eurobalt.org.pl as of 10 March 2008 cited in: K. Gomólka, Wspótpraca transgraniczna Polski z Republikq Ukrainy, Republikq Biatorusi i Obwodem Kaliningradzkim Federacji Rosyjskiej, Wyd. Semper, Warszawa 2011.

Pomorskie Province Office in Gdańsk, 2003 Activity Report. Polish-Russian co-operation, Gdańsk 2004.

Pomorskie Province Office in Gdańsk, $2^{\text {nd }}$ Forum of Partner Regions of Kaliningrad Oblast, Gdańsk.

Pomorskie Province Office in Gdańsk, $3^{\text {rd }}$ Tourism Forum of the Baltic Sea Region, Gdańsk 2010.

Pomorskie Province Office in Gdańsk, Economic Forum, Starogard Gdański 2000.

Pomorskie Province Office in Gdańsk, Information on the talks of the Polish-Russian Intergovernmental Commission on Economic Cooperation, The Working Group on Trade and Investment, Gdańsk.

Pomorskie Province Office in Gdańsk, Meeting between the delegation from Pomorskie province and the representatives of Kaliningrad Duma in February 2000, Gdańsk 2000.

Pomorskie Province Office in Gdańsk, Memo. Cooperation with Euroregion Baltic, Gdańsk.

Pomorskie Province Office in Gdańsk, Memo. Festival of Sea Songs, Gdańsk 2006.

Pomorskie Province Office in Gdańsk, Polish-Russian Debate: The future of Kaliningrad Oblast in the expanding Europe, Gdańsk.

Pomorskie Province Office in Gdańsk, Project of Economic Revitalisation of the Vistula River Delta and the Vistula Lagoon, Agreement no. FW-SPF-97/2003/710/II of 6 July 2005 financed by the European Union funds under PHARE 2003 as part of Polish Eastern Border implemented by the Association of Polish Communes Euroregion Baltic, http://www.pomorskie.eu/res/wizytowka/rolnictwo/program_ rewitalizacji.pdf (07.07.2013).

Pomorskie Province Office in Gdańsk, Report on the meeting in October 2007, Gdańsk 2008; Pomorskie Province Office in Gdańsk, Report on the participation in the Forum of Partner Regions of Kaliningrad Oblast, Gdańsk 2008.

Pomorskie Province Office in Gdańsk, Strategy for the development of Pomorskie province, Gdańsk 2000. 
Pomorskie Province Office in Gdańsk, Strategy for the development of Pomorskie province, http://strategia2020.pomorskie.eu/res/strategia2020/strategia2005/asrwp_ tekst_jednolity_ostateczny_180705.pdf (02.07.2013).

Pomorskie Province Office in Gdańsk, Strategy for the development of Pomorskie province until 2010, http://urzad.pomorskie.eu/res/umwp/dokumenty/pomorskie_ srwp2020.pdf (03.07.2013).

Pomorskie Province Office in Gdańsk, Wizyty studyjne, Gdańsk 2005.

Pomorskie.eu, The administrative division of Pomorskie province, http://www.pomorskie. $\mathrm{eu} / \mathrm{pl}(01.07 .2013)$.

Pomorskie.eu, The Agreement on cooperation between Pomorskie Province (Republic of Poland) and the Administration of Kaliningrad Oblast (Russian Federation) of $27 \mathrm{Feb}-$ ruary 2002, http://www.pomorskie.eu/p1/bip/umwp/urzad/sprawy/sprawy_do_zalatwienia/dwz_porozumienia (07.07.2013).

Pomorskie.eu, The agreement on the cooperation between Sejmik of Pomorskie and Duma of Kaliningrad Oblast of 27 February 2002, http://www.pomorskie.eu/p1/bip/umwp/urzad/sprawy/sprawy_do_zalatwienia/dwz_porozumienia (07.07.2013).

Pomorskie.eu, The Priorities of the Foreign Cooperation of Pomorskie Province, http://www. pomorskie.eu/res/BIP/UMWP/wojewodztwo/wspolpraca_zag.pdf (05.07.2013).

Pracodawcypomorza.pl, Battyckie Forum Biznesu 2012 r., http://pracodawcypomorza. pl/2012/01/27/baltyckie-forum-biznesu-gdansk-2012-9-02-2012/ (08.07.2013).

Rzeki.art.pl, Tczerw bulwar, aktywna przestrzen, http://www.rzeki.art.pl/filemanager/file/prezentacje/Tczew_bulwar.pdf (07.07.2013).

Seagull in a nutshell, „Euroregion Baltic Bulletin”, No. 3/2007.

The Agreement between the Government of the Republic of Poland and the Government of the Russian Federation on cooperation of the north-eastern voivodeships in Poland and Kaliningrad Oblast.

The Agreement between the Government of the Republic of Poland and the Government of the Russian Federation on cooperation of Polish voivodeships with the region of Saint Petersburg of 22 May 1992 - the text of the agreement in: T. Baryła, W. Hojszyk (ed.), Regiony i Pogranicza. Kaliningrad. Fakty i wydarzenia, opinie, TN, OBN Olsztyn, Olsztyn 2007, No 2.

The Agreement between the Government of the Republic of Poland and the Government of the Russian Federation on cross-border cooperation of 2 October 1992 [in:] A. Przyborowska-Klimczak, W. Staszewski, S. Wrzosek (ed.), Prawnomiędzynarodowe zródta wspótpracy regionalnej wspótpracy regionalnej Polski. Wybór dokumentów. Wydawnictwo Ekonomia i Środowisko, Fundacja Ekonomistów Środowiska i Zasobów Naturalnych, Białystok 2000.

The Agreement between the Government of the Republic of Poland and the Government of the Russian Federation on the travelling conditions of citizens of both states of $18 \mathrm{Sep-}$ tember 2003, Law Gazette, No. 51/2003, it. 800.

The Agreement between the Government of the Republic of Poland and the Government of the Russian Federation on the sailing on the Vistula Lagoon of 1 September 2009, Law Gazette, No. 78/2009, it. 975. 
The Treaty of Good Neighbourship and Friendly Cooperation between the Republic of Poland and the Russian Federation, signed on 22 May 1992 in Moscow, Journal of Laws of 1993, No. 61, it. 291.

Trojmiasto.pl, Do Bałtyjska popłyniemy już w sobotę, http://www.trojmiasto.pl/wiadomosci/Do-Baltijska-poplyniemy-juz-w-sobote-n41837.html (08.07.2013). 
